\title{
Wybrane zagadnienia dokładnego wyznaczania wartości prędkości krytycznej modelu pojazdu szynowego
}

\begin{abstract}
Stateczność ruchu pojazdu szynowego na torze zakrzywionym - to ogólne zagadnienie badawcze, które stanowi przedmiot wieloletnich badań autorów [612] i którego fragment zawiera niniejszy artykut. Podstawowym parametrem używanym $w$ analizie stateczności ruchu jest prędkość krytyczna. $W$ dotychczasowych badaniach autorzy wyznaczali prędkość krytyczna $w$ sposób przybliżony. Pozwalato to na ograniczenie ilości badań symulacyjnych i skrócenie czasu ich realizacji. Istota badań, których wyniki zamieszczono $w$ artykule, jest precyzyjne wyznaczenie wartości prędkości krytycznej i porównanie nowych wartości z wcześniej wyznaczonymi w sposób przybliżony. Parametrem, który jest przedmiotem zainteresowania $w$ badaniach sq przemieszczenia poprzeczne zestawów kolowych.
\end{abstract}

\section{Wstęp}

Ruch pojazdu szynowego jest przedmiotem badań teoretycznych i doświadczalnych od początku istnienia tego rodzaju środka transportu. Dziesięciolecia badań i rozwoju doprowadziły do wyodrębnienia się pewnych dziedzin jak np.: bezpieczeństwo ruchu, komfort, stateczność, zagadnienia związane z trwałością i niezawodnością oraz inne. Autorzy niniejszej publikacji prowadzą badania teoretyczne zaliczane do analizy stateczności ruchu. W sposób pośredni odnoszą się one również do bezpieczeństwa ruchu. Obiektem badań jest model numeryczny układu mechanicznego pojazd szynowy - tor. Pozwala on na obliczenie wybranych parametrów kinematycznych i dynamicznych dla dowolnych zadanych warunków ruchu. Przedmiotem dotychczasowych analiz było określenie wpływu na stateczność ruchu czynników takich jak: parametry układu zawieszenia modelu pojazdu, rodzaj zarysów kół i szyn, zużycie zarysów, przechyłka toru, pochylenie szyn i inne [6-12]. W większości badanych przypadków obserwacji i analizie poddane zostały przemieszczenia poprzeczne atakującego zestawu kołowego y. W zależności od przyjętych układów współrzędnych i rodzaju trasy parametr ten (rozwiązania układu), może przyjmować wartości ujemne lub dodatnie. Ponieważ z punktu widzenia stateczności istotna jest wartość (znak informuje o kierunku przemieszczeń), przyjmowano więc do analizy wartość bezwzględną przemieszczeń poprzecznych zestawu kołowego. Przykładowe przebiegi zmian przemieszczeń poprzecznych $\mathrm{w}$ funkcji drogi pokonywanej przez model przedstawia rysunek $2.3 \mathrm{c}$ i d. Jak można zauważyć parametr ten może dążyć do przyjęcia wartości stałej (c) lub zmiennej (d). W pierwszym przypadku charakter rozwiązań nazywany jest stacjonarnym (quasistatycznym). Początkowe zmiany wynikają z nałożenia na oba zestawy kołowe wymuszeń początkowych. W drugim przypadku zmiany maja charakter okresowy o stałej częstotliwości i amplitudzie. Nazywane są rozwiązaniami okresowymi i mają charakter cyklu granicznego. Oba typy rozwiązań należą do rozwiązań statecznych. Oznacza to niezmienność ruchu (i rozwiązania) na dowolnie długim odcinku toru. Widoczna asymetria przemieszczeń względem linii zerowej wynika z ruchu po łuku z prędkością, dla której występuje niedobór przechyłki toru. Prędkość ruchu modelu jest jednym z parametrów decydujących o charakterze rozwiązań (stacjonarne lub okresowe) przy założeniu, że wszystkie inne parametry układu pozostaja stałe. Rozwiązania stacjonarne występują przy mniejszych prędkościach. Z uwagi na fakt, że badany model umożliwia zadanie jednej stałej wartości prędkości w danej symulacji ruchu, chcąc wykonać obliczenia dla innej należy przeprowadzić nową symulację zmieniając wartość prędkości z określonym krokiem. Najmniejsza zadana prędkość ruchu, dla której pojawią się rozwiązania okresowe o charakterze cyklu granicznego nazywana jest prędkością krytyczną układu nieliniowego $v_{n}$. W literaturze prędkość ta nazywana jest również prędkością podkrytyczną punktu bifurkacji Hopfa. Wystapienie w układzie prędkości krytycznej $v_{n}$ nie musi oznaczać wykolejenia, ponieważ zakres okresowych przemieszczeń poprzecznych zestawu kołowego mieści się $\mathrm{w}$ przedziale stosowanego luzu poprzecznego zestaw kołowy - tor. Z punktu widzenia stateczności ruchu najistotniejsze 
jest wyznaczenie wartości prędkości krytycznej oraz maksymalnej prędkości, dla której rozwiązania mają jeszcze charakter cyklu granicznego lub stacjonarny (największej możliwej prędkości).

W dotychczasowych badaniach autorzy wyznaczali prędkość krytyczną w symulacjach ruchu na torze prostym, traktując ją jako punkt wyjścia. Następnie wyznaczali prędkości krytyczne w łukach, przyjmując domniemanie, że prędkości $v_{n} \mathrm{~W}$ łukach będą takie same i równe prędkości krytycznej wyznaczonej na torze prostym. W zdecydowanej większości przypadków domniemanie to potwierdziło się. Stąd przyjmowano jedną wartość oddzielającą zakres rozwiązań stacjonarnych od rozwiązań okresowych na wszystkich badanych trasach (łukowych o promieniach $R=600 \mathrm{~m}-\infty$, rys. 5 i 6 ). Ze względu na uproszczony charakter wyznaczania prędkości $v_{n} \mathrm{~W}$ niniejszej pracy podjęto próbę zweryfikowania dokładności wartości $v_{n}$ wyznaczonych w poprzednich badaniach.

Badany układ mechaniczny należy do grupy tzw. układów o sztywnym charakterze pobudzenia. Oznacza to, że dla parametrów ruchu spełniających warunki wystapienia rozwiązań okresowych (drgań samowzbudnych w układzie rzeczywistym), układ wymaga wymuszenia początkowego o określonej wartości aby rozwiązania stacjonarne zmieniły charakter na okresowy. Rysunek 1 przedstawia charakter rozwiązań (przemieszczeń poprzecznych atakującego zestawu kołowego) w funkcji drogi pokonywanej przez model na torze prostym, przy stałej prędkości ruchu $43 \mathrm{~m} / \mathrm{s}$ i różnych wymuszeniach początkowych (przemieszczeniach poprzecznych zestawów względem toru). Jak można zauważyć dla wymuszeń mniejszych od $0,00021 \mathrm{~m}$ amplitudy przemieszczeń mają charakter malejący, rozwiązania przyjmują charakter stacjonarny (quasi-statyczny). Wartością graniczną (minimalną) wymuszeń początkowych, dla której następuje zmiana charakteru rozwiązań na okresowy jest $0,00022 \mathrm{~m}$. Można więc zauważyć, że bardzo małe zmiany wartości wymuszeń początkowych $(0,01 \mathrm{~mm})$ maja istotny wpływ na charakter rozwiązań a zatem $i$ na stwierdzenie wystapienia krytycznej wartości prędkości ruchu. Większe od $0,00022 \mathrm{~m}$ wymuszenia początkowe nie mają wpływu na charakter rozwiązań a jedynie na skrócenie drogi, na której następuje stabilizacja wartości amplitudy przemieszczeń. Przedstawione na rys. 1 wyniki uzyskano z modelu wyposażonego w tablice parametrów kontaktowych utworzoną dla kół o zarysach S1002 i szyn UIC60. Dla innych konfiguracji zarysów graniczna wartość wymuszeń początkowych ma inną wartość. Na przykład dla zarysów kół typu BRP10 i szyn UIC60 jest to $0,0045 \mathrm{~m}$, a więc dla konkretnych konfiguracji modelu wymuszenia decydujące o charakterze rozwiązań mogą różnić się w sposób znaczący. Wykonując wielokrotne symulacje ruchu). dla poszczególnych konfiguracji modelu stwierdzono, że wymuszenia początkowe o wartości $0,0045 \mathrm{~m}$ są w każdym przypadku dostatecznie dużą w artością do zainicjowania rozwiązań okresowych (drgań samowzbudnych), jeżeli spełnione są warunki sprzyjające transformacji energii ruchu roboczego modelu pojazdu do układu drgającego ( przemieszczenia poprzeczne zestawów kołowych

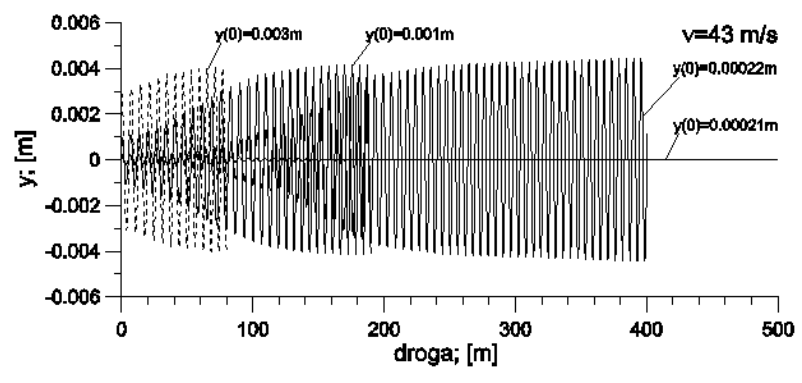

Rys. 1. Wpływ wartości wymuszeń początkowych y(0) na charakter rozwiązań badanego układu

Dlatego $\mathrm{w}$ dotychczasowych badaniach zadawano wymuszenia o wartości $0,0045 \mathrm{~m}$ w każdej symulacji. Decyzji takiej towarzyszyła świadomość przybliżonego wyznaczania wartości prędkości krytycznej i potencjalnej możliwości pomijania rozwiązań wielokrotnych. Podyktowana była przede wszystkim potrzebą skrócenia czasu obliczeń. Zwiększenie dokładności wyznaczania prędkości krytycznej w niniejszym artykule osiagnięto poprzez zmniejszenie interwału prędkości pomiędzy poszczególnymi symulacjami i wariantowanie (skrupulatne przeszukiwanie) zakresu warunków początkowych.

\section{Model i metoda}

Badany układ mechaniczny to model pojazdu szynowego dwuosiowego z jednym stopniem usprężynowania (rys. 2). Odpowiada on strukturze wagonu towarowego HSFV1 kolei brytyjskich [5]. Model wagonu uzupełniono o poprzecznie i pionowo podatny model toru (rys. 3). Model wagonu i toru są badane łącznie, stanowiąc dyskretny układ pojazd szynowy - tor. Model matematyczny układu zbudowano zgodnie $\mathrm{z}$ metodyką uogólnionego modelowania dynamiki pojazdów szynowych przedstawioną w [5].

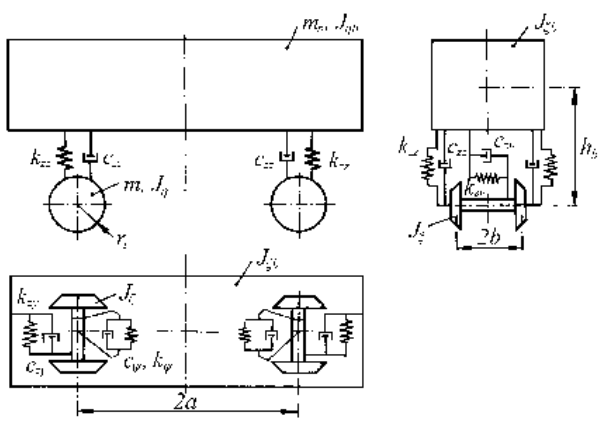

Rys. 2. Struktura modelu pojazdu 
a)

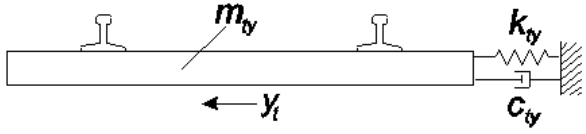

b)

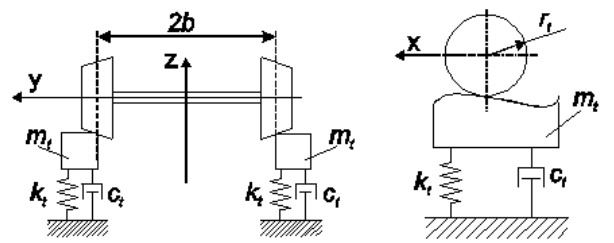

Rys. 3. Struktura modelu toru podatnego: a) poprzecznie, b) pionowo
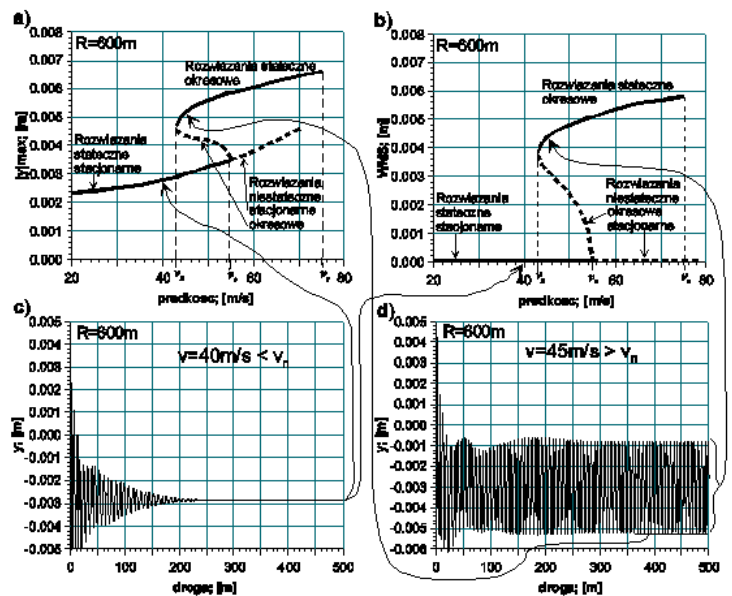

Rys. 4. Schemat metody tworzenia wykresów bifurkacyjnych
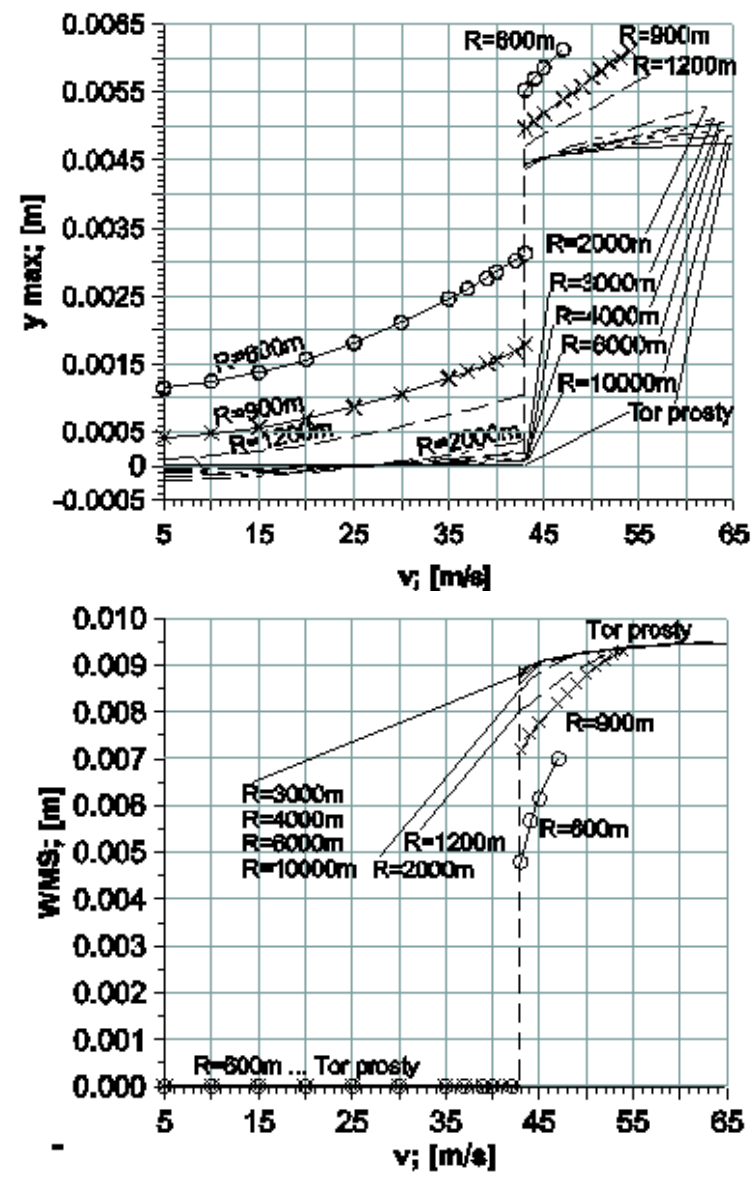

Rys. 5. Wykresy stateczności ruchu modelu z konfiguracją zarysów kół S1002 i szyn UIC60
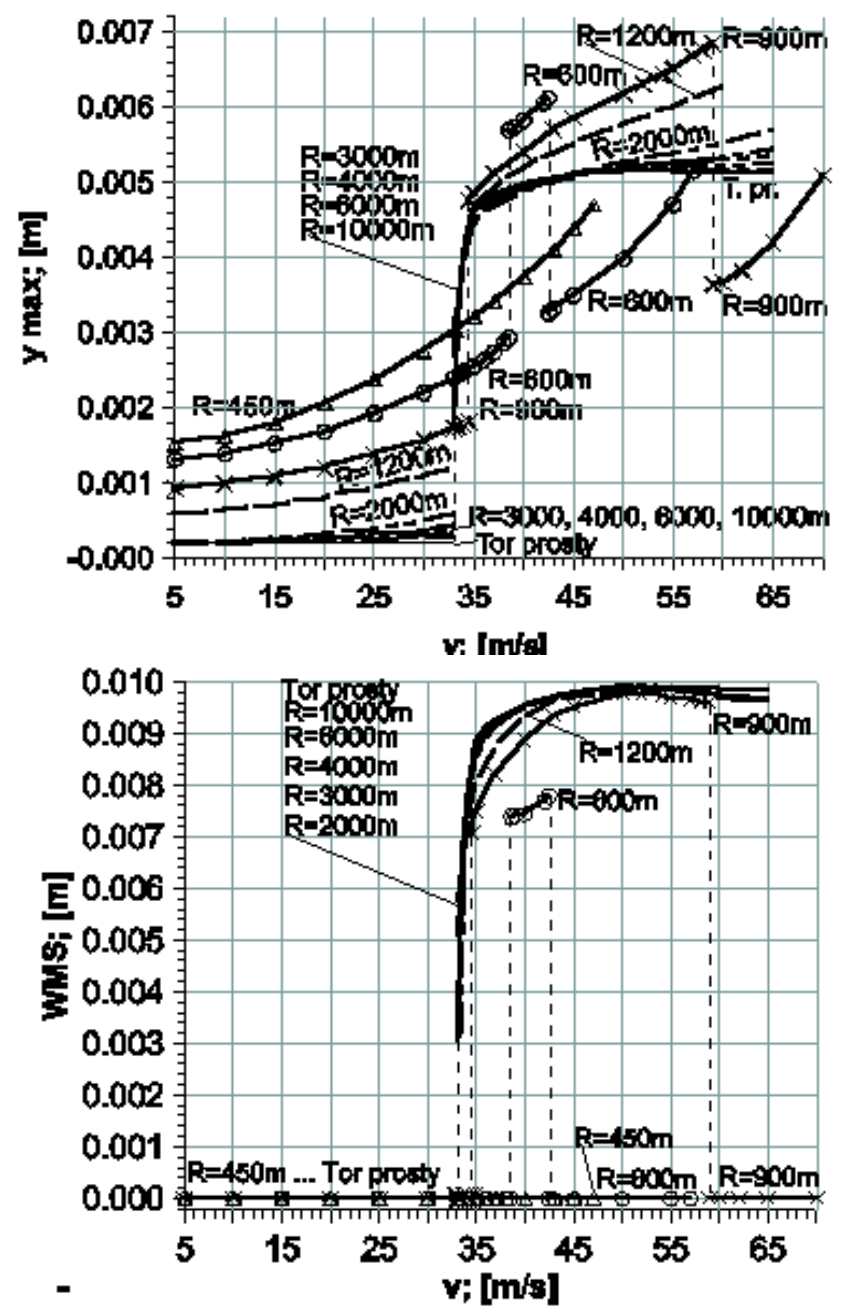

Rys. 6. Wykresy stateczności ruchu modelu z konfiguracją zarysów kół S1002 i szyn S49

$\mathrm{Na}$ rysunku 4 przedstawiono schemat metody tworzenia wykresów bifurkacyjnych (map stateczności ruchu). Szczegółowy opis metody można znaleźć w [7, 8, 9, 12].

\section{Wyniki badań}

Poniżej przedstawiono wyniki uzyskane z badań modelu wykorzystującego tablice parametrów kontaktowych dla par zarysów kół i szyn kolejno: S1002/UIC60, BR-P10/UIC60, S1002/S49. Ze względu na ograniczoną objętość artykułu przedstawiono tylko kilka wybranych wyników i krótką ich interpretacje. Zamieszczone na rysunkach 5 i 6 wyniki wcześniejszych badań stanowią bazę porównawczą dla wyników bieżących.

\subsection{Model z zarysami kół i szyn S1002/UIC60}

Łuk o promieniu $R=600 \mathrm{~m}$, posiada najmniejszą wartość promienia, dla którego możliwe jest zidentyfikowanie prędkości krytycznej $v_{n}$ oraz rozwiązań statecznych okresowych w obszarze prędkości nadkrytycznych, dla tej konfiguracji zarysów kół i szyn. Jak można zauważyć na rys. 7, pierwotnie określona wartość prędkości krytycznej (na torze prostym) $43 \mathrm{~m} / \mathrm{s}$, 
nieznacznie różni się od precyzyjnie wyznaczonej wartości $v_{n}=42,7 \mathrm{~m} / \mathrm{s}$. Przy tej prędkości graniczna wartość wymuszeń początkowych $y_{p}(0)$ wynosi 0,0039 m. Dla wartości $y_{p}(0)$ mniejszych od $0,0039 \mathrm{~m}$ występowały rozwiązania stateczne stacjonarne, dla $y_{p}(0)$ większych od $0,0039 \mathrm{~m}$ rozwiązania stateczne okresowe o charakterze cyklu granicznego.
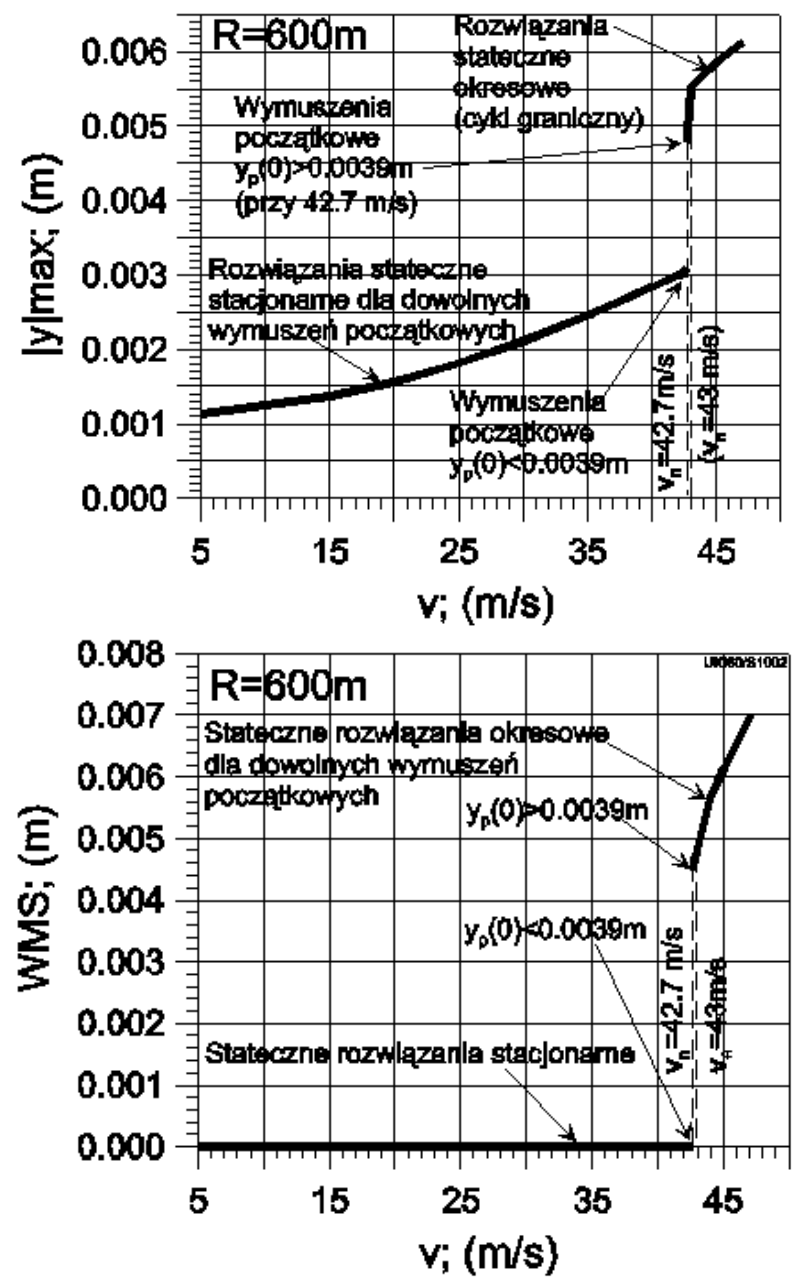

Rys. 7. Wykresy stateczności ruchu dla zarysów S1002/UIC60 na trasie o promieniu $R=600 \mathrm{~m}$

Na trasie o większym promieniu łuku $R=900 \mathrm{~m}$, różnica pomiędzy wartością prędkości $v_{n}$ określonej pierwotnie i dokładnie wzrosła (wykresy pominięto). W tym przypadku $v_{n}=39,8 \mathrm{~m} / \mathrm{s}$, co jest wartością mniejszą od wartości określonej pierwotnie o 3,2 m/s. Graniczna wartość wymuszeń początkowych wynosi $y_{p}(0)=0,0013 \mathrm{~m}$.

Zwiększenie promienia łuku do $1200 \mathrm{~m}$ powoduje zmniejszenie wartości prędkości krytycznej do 39,4 $\mathrm{m} / \mathrm{s}$ (rys. 8). Jest to najmniejsza prędkość, przy której pojawiają się rozwiązania okresowe a graniczna wartość wymuszeń początkowych wynosi 0,0014 m. Występuje tutaj również w zakresie prędkości ruchu 39,4-40,1 m/s, obszar rozwiązań wielokrotnych zależnych od wymuszeń początkowych.
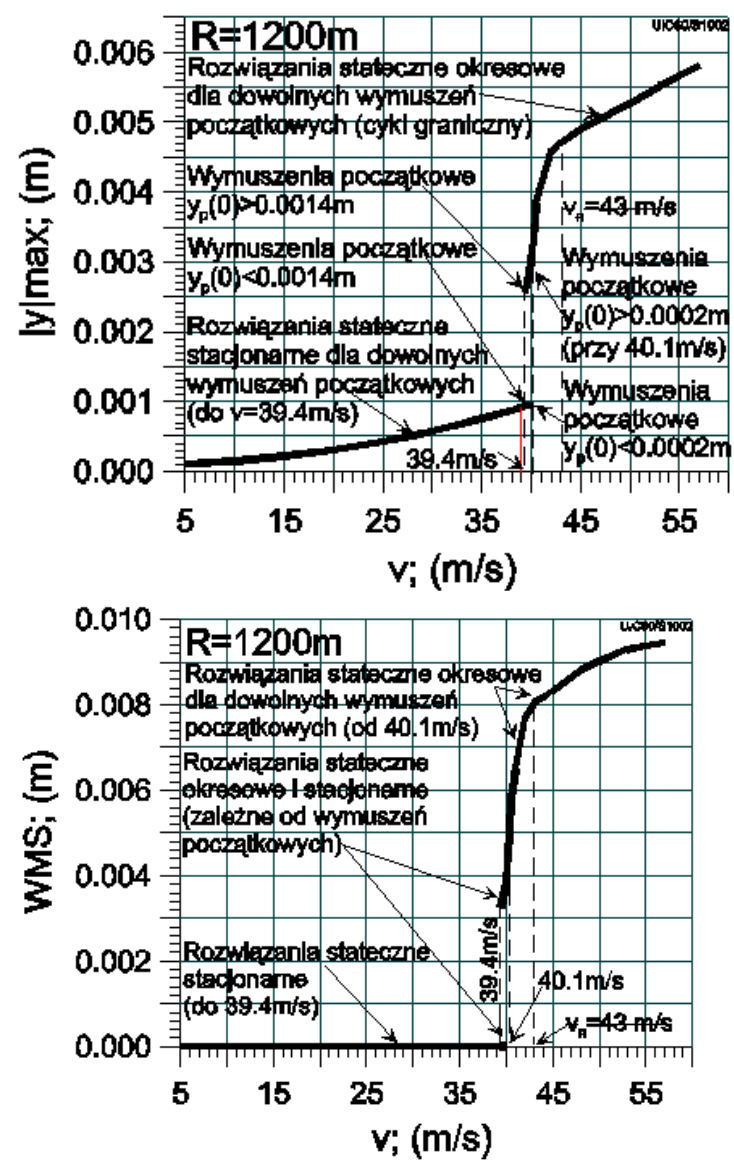

Rys. 8. Wykresy stateczności ruchu dla zarysów S1002/UIC60 na trasie o promieniu $\mathrm{R}=1200 \mathrm{~m}$
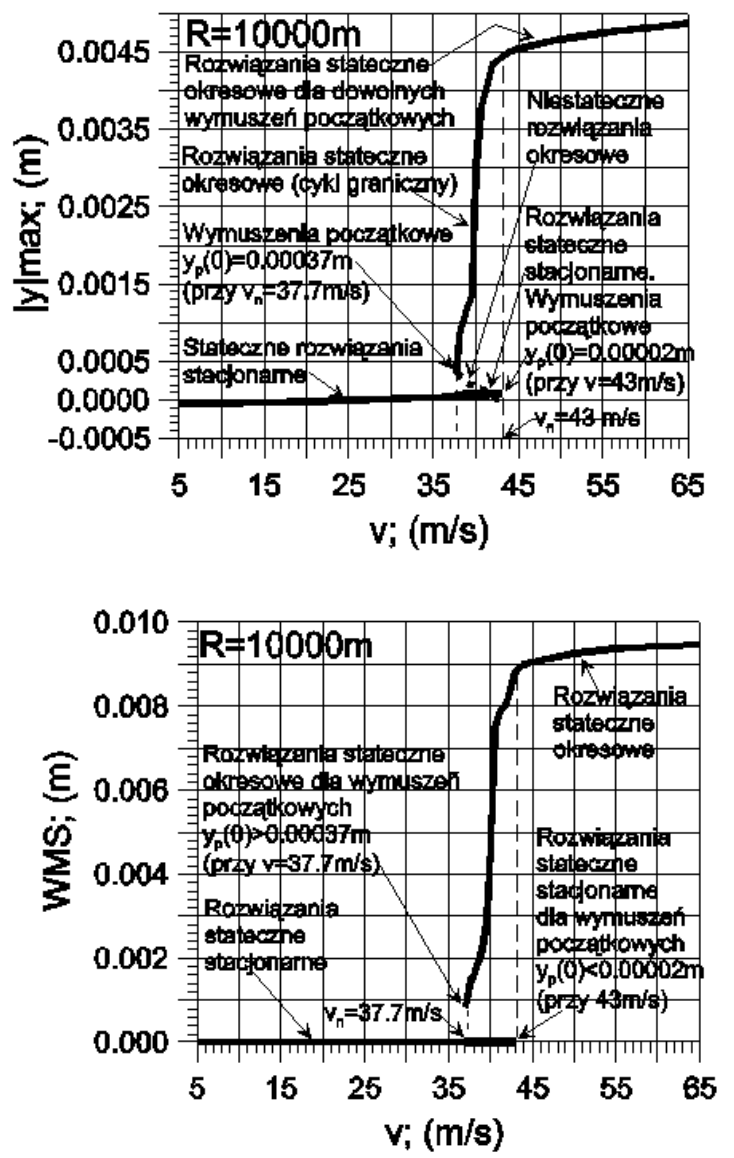

Rys. 9. Wykresy stateczności ruchu dla zarysów S1002/UIC60 na trasie o promieniu $\mathrm{R}=10000 \mathrm{~m}$ 

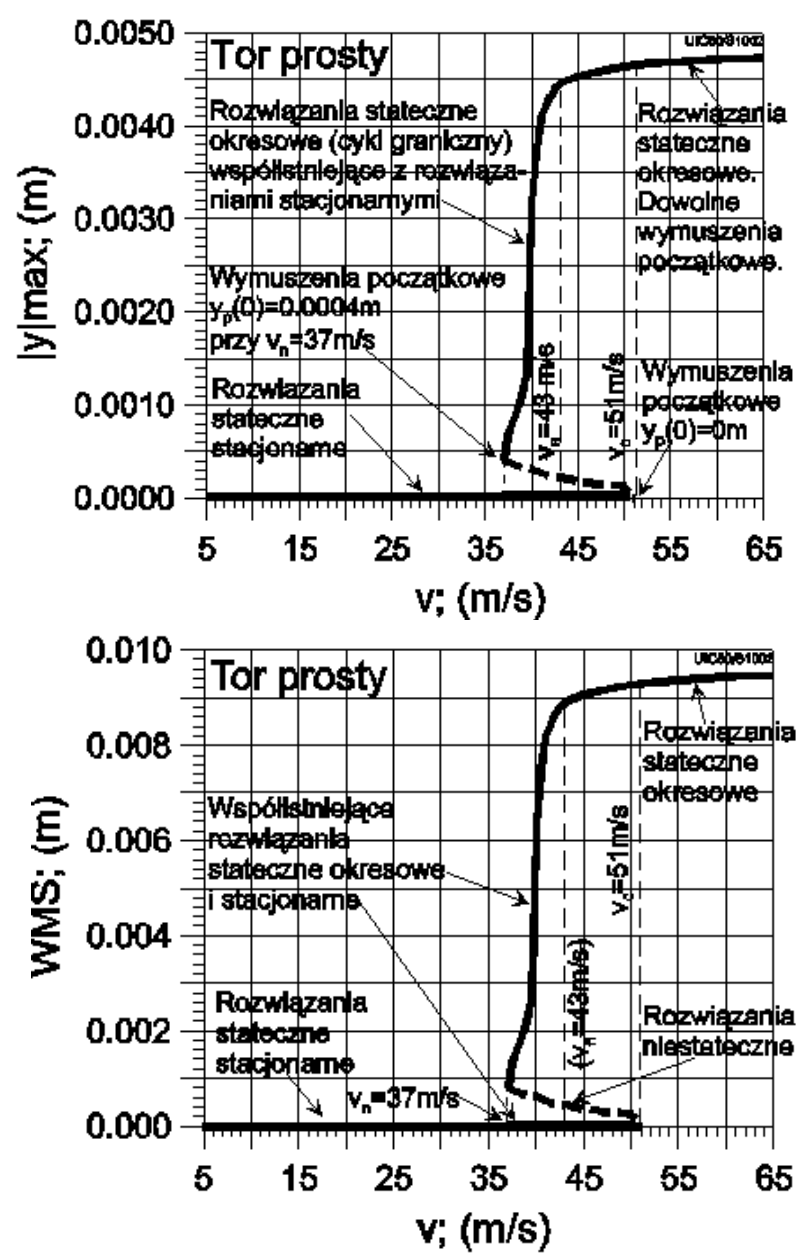

Rys. 10. Wykresy stateczności ruchu modelu z zarysami kół i szyn S1002/UIC60 na torze prostym

$\mathrm{Na}$ trasie o dużym promieniu łuku $\mathrm{R}=10000 \mathrm{~m}$ prędkość krytyczna ma jeszcze mniejszą wartość 37,7 $\mathrm{m} / \mathrm{s}$ (rys. 9). Graniczna wartość wymuszeń początkowych wynosi $0,00037 \mathrm{~m}$.

W porównaniu do poprzednich przypadków zwiększył się tutaj zakres prędkości $(37,7-43 \mathrm{~m} / \mathrm{s})$, w którym występują rozwiązania wielokrotne zależne od wartości wymuszeń początkowych.

$\mathrm{Na}$ torze prostym różnica pomiędzy prędkością krytyczną wyznaczoną ,zgrubnie” a tą wyznaczoną precyzyjnie osiagnęła największą wartość (rys. 10). Dla wymuszeń początkowych $y_{p}(0) \geq 0,0004 \mathrm{~m}$, rozwiązania okresowe pojawiają się przy prędkości 37 $\mathrm{m} / \mathrm{s}$. Jest tutaj również najszerszy zakres prędkości (37-51 m/s), w którym występują rozwiązania wielokrotne zależne od wymuszeń początkowych.

\subsection{Model z zarysami kół i szyn BR-P10/UIC60}

W poprzednio wykonanych badaniach prędkość krytyczną modelu z zarysami kół BR-P10 i szyn UIC60, na torze prostym, zidentyfikowano przy 45,3 $\mathrm{m} / \mathrm{s}$ (rys. 11). Zwiększając wymuszenia początkowe od 0 do $0,0054 \mathrm{~m}$, rozwiązania okresowe pojawiły się przy prędkości $41,6 \mathrm{~m} / \mathrm{s}$. Wartości wymuszeń początkowych $y_{p}(0)>0,0054 \mathrm{~m}$, nie miały już żadnego wpływu na charakter rozwiązań dla prędkości ruchu mniejszych od $41,6 \mathrm{~m} / \mathrm{s}$. Otrzymano w ten sposób nową wartość $v_{n}$ na torze prostym. Należy zaznaczyć, że w tym przypadku na trasach łukowych wymuszenia początkowe nie miały żadnego wpływu na charakter rozwiązań dla prędkości ruchu mniejszych od $45,3 \mathrm{~m} / \mathrm{s}$. A więc pierwotnie określona wartość prędkości krytycznej na trasach będących łukami pozostała słuszna (wyniki badań - pominięto).
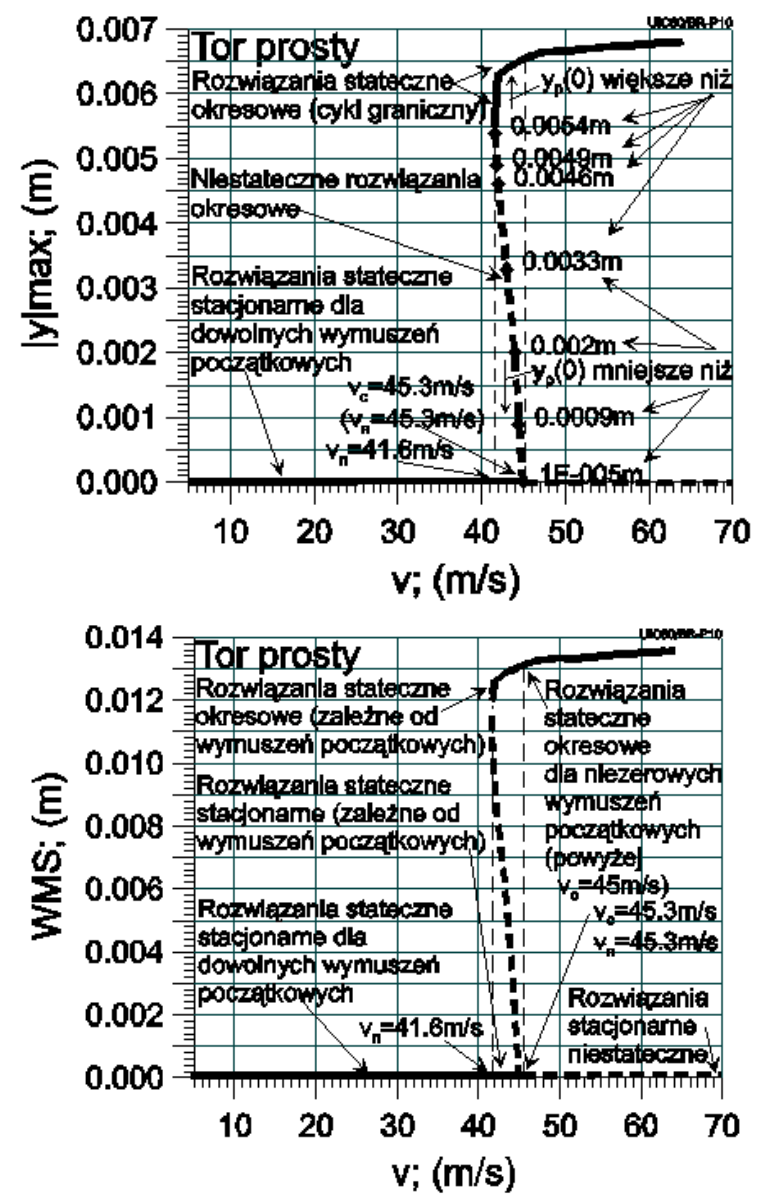

Rys. 11. Wykresy stateczności ruchu modelu z zarysami kół i szyn BR-P10/UIC60 na torze prostym

\subsection{Model z zarysami kół i szyn S1002/S49}

Dla modelu z zarysami kół S1002 i szyn S49 w poprzednich badaniach prędkość krytyczna została zidentyfikowana na torze prostym przy $33,2 \mathrm{~m} / \mathrm{s}$ (rys. 6 i 13). Wartość ta nie uległa zmianie mimo uszczegółowienia badań. Model $\mathrm{z}$ rozważanymi zarysami charakteryzował się rozwiązaniami statecznymi stacjonarnymi na trasach o małych promieniach łuków (600 i $900 \mathrm{~m}$ ), w pewnych zakresach prędkości ruchu większych od wartości krytycznej (rys. 6). Szczegółowe badania na trasie o promieniu tuku $600 \mathrm{~m}$, przy zmienianych $\mathrm{w}$ szerokim zakresie wymuszeniach początkowych wykazały, że najmniejsza prędkość ruchu, przy której pojawiają się rozwiązania okresowe wynosi 38,5 m/s (rys. 12). Graniczna wartość 
wymuszeń początkowych $y_{p}(0)=0,0016 \mathrm{~m}$. A więc na tej trasie $v_{n}=38,5 \mathrm{~m} / \mathrm{s}$. Na torze prostym graniczna wartość wymuszeń początkowych wynosi $0,003 \mathrm{~m} \mathrm{i}$ maleje wraz ze wzrostem prędkości osiagając zero przy $34,1 \mathrm{~m} / \mathrm{s}$ (rys. 13).
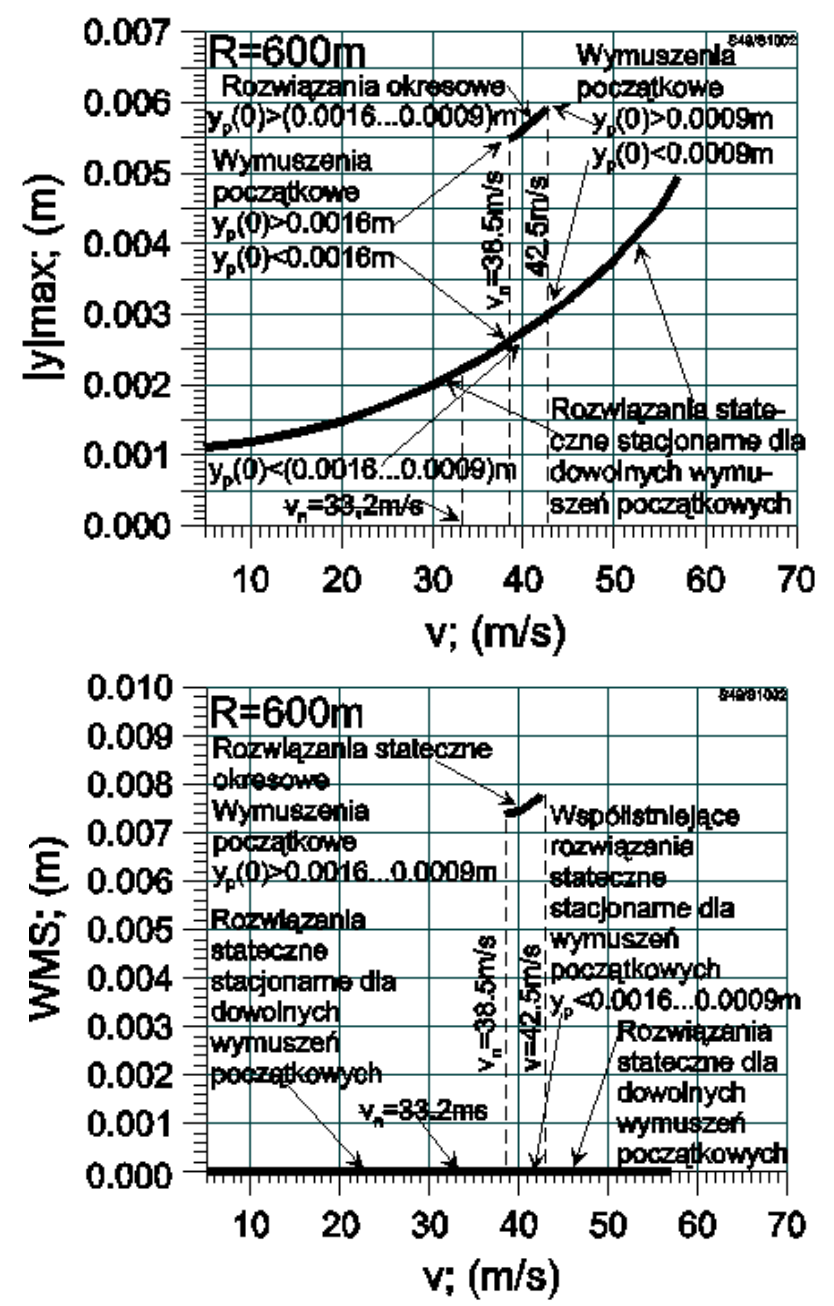

Rys. 12. Wykresy stateczności ruchu modelu dla zarysów $\mathrm{S} 1002 / \mathrm{S} 49$ na trasie o promieniu $\mathrm{R}=600 \mathrm{~m}$

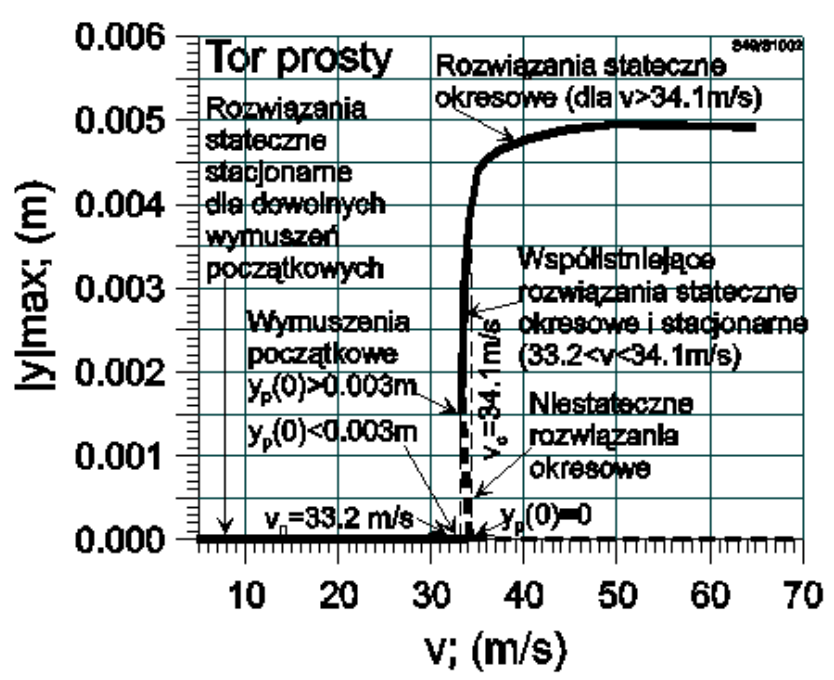

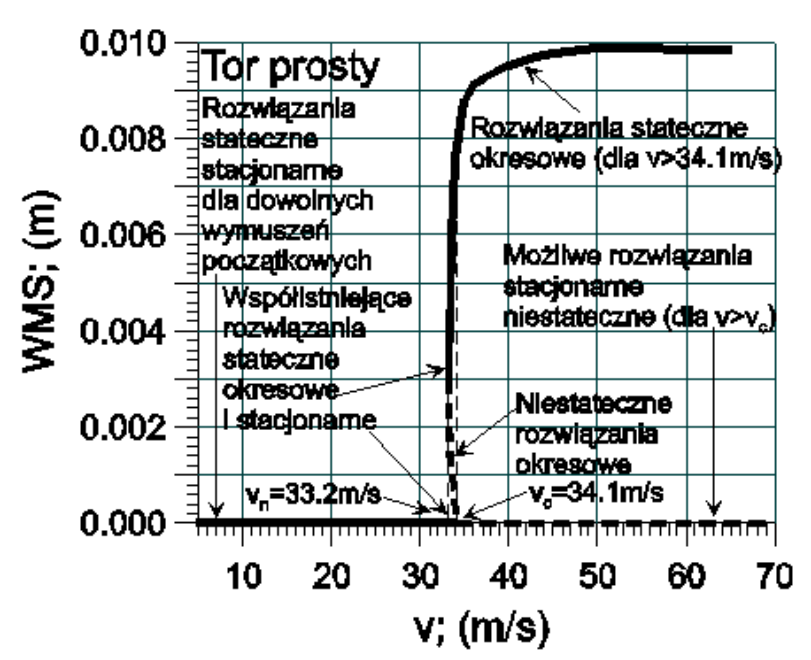

Rys. 13. Wykresy stateczności ruchu modelu z zarysami kół i szyn S1002/S49 na torze prostym

\section{Wnioski}

Wymuszenia początkowe mają istotny wpływ na dokładność określenia wartości prędkości krytycznej na torze prostym. Na trasach łukowych wpływ wymuszeń początkowych maleje wraz ze zmniejszaniem wartości promienia łuku trasy. Wartości wymuszeń poczattkowych decydujące o charakterze rozwiązań układu, mogą różnić się znacząco w zależności od konkretnych konfiguracji tego samego modelu. Należy mieć na uwadze fakt, że badany układ jest wielowymiarowy. A więc pełną informację o wartości prędkości krytycznej, mogą dać badania wykonane dla wymuszeń początkowych zadawanych na poszczególne bryły modelu we wszystkich możliwych kierunkach przemieszczeń.

Praca naukowa finansowana ze środków na naukę $M N$ i $S W$ w latach 2009-20011 jako projekt badawczy $n$ r N N509 403136.

\section{Literatura}

[1] Mo elle D., Gasch R., Nonlinear bogie hunting, in ed.: A. Wickens, Proc. 7th IAVSD Symposium, Cambridge, UK. Swets \& Zeitlinger, Lisse, pp. 455-467, 1982.

[2] True H., Jensen Ch., Parameter study of hunting and chaos in railway vehicle dynamics, Proceedings of $13^{\text {th }}$ IAVSD Symposium, supplement to Vehicle System Dynamics, vol. 23, pp. 508-521, 1993.

[3] True H., Railway vehicle chaos and asymmetric hunting, Proc. of $12^{\text {th }}$ IAVSD Symposium, supplement to Vehicle System Dynamics, vol. 20, pp. 625-637, 1991.

[4] Zboiński K., Dynamical investigation of railway vehicles on a curved track, European Journal of Mechanics, Part A Solids, vol. 17, no. 6, pp. 1001-1020, 1998.

[5] Zboiński K., Metodyka modelowania dynamiki pojazdów szynowych z uwzględnieniem zadanego ruchu unoszenia i jej zastosowania, Prace Naukowe Transport, z. 43, Oficyna Wydawnicza Politechniki Warszawskiej, Warszawa 2000. 
[6] Zboiński K., Dusza M., Komputerowe badania wplywu przechyłki toru na stateczność pojazdu szynowego w tuku, Zeszyty Naukowe Politechniki Ślaskiej, Transport, Zeszyt 49, str. 295-304, Gliwice 2003.

[7] Zboinski K., Dusza M., Analysis and method of the analysis of non-linear lateral stability of railway vehicles in curved track, Proceedings of $18^{\text {th }}$ IAVSD Symposium, Kanagawa 2003, supplement to Vehicle System Dynamics vol. 41, pp. 222-231, 2004.

[8] Dusza M., Zboiński K., Badania stateczności ruchu pojazdu szynowego $w$ torze zakrzywionym metoda symulacji komputerowej, Kwartalnik $\mathrm{Na}$ ukowo-Techniczny Pojazdy Szynowe nr 2/2004, str. 28-34.

[9] Zboiński K., Dusza M., Development of the method and analysis for non-linear lateral stability of railway vehicles in a curved track, Proceedings of $19^{\text {th }}$ IAVSD Symposium, Milan 2005, supplement to Vehicle System Dynamics vol. 44, pp. 147-157, 2006.
[10] Zboiński K., Dusza M., Analysis of lateral stability of a railway vehicle model in the context of different values of rail inclination, Proceedings of $10^{\text {th }}$ VSDIA Conference, pp. 153160, Budapest 2006.

[11]Zboiński K., Dusza M., Bifurcation approach to the influence of rolling radius modelling and rail inclination on the stability of railway vehicle in a curved track, Proceedings of $20^{\text {th }}$ IAVSD Symposium, Berkeley 2007, supplement to Vehicle System Dynamics, vol. 46, pp. 1023-1037, 2008.

[12]Zboiński K., Dusza M., Self-exciting vibrations and Hopf's bifurcation in non-linear stability analysis of rail vehicles in curved track, European Journal of Mechanics, Part A/Solids, vol. 29, no. 2, pp. 190-203, 2010. 